\title{
Profit Maximization Versus Stakeholders' View of Corporate Social Responsibility: An Experiential Exercise on Ethics and Social Responsibility for Business School Courses
}

\author{
Sukumar C. Debnath ${ }^{1}$, Sudhir R. Tandon ${ }^{1} \&$ B. Brian Lee ${ }^{1}$ \\ ${ }^{1}$ College of Business, Prairie View A\&M University, Prairie View, Texas, USA \\ Correspondence: Sukumar Debnath, College of Business, M.S. 2300, Prairie View A\&M University, Prairie View, \\ Texas 77446, USA.
}

Received: October 24, 2018

Accepted: November 14, 2018

Online Published: November 26, 2018

doi:10.5430/ijba.v9n6p69

URL: https://doi.org/10.5430/ijba.v9n6p69

\begin{abstract}
While issues related to ethics and social responsibility have gained tremendous significance in corporate and academic worlds during the recent times, these concepts are difficult to grasp and even more difficult to teach in a classroom setting. This experiential exercise serves as a vehicle for students to enhance their understanding and insights on these concepts as they critically examine, in a highly involved setting, the two opposing views of corporate social responsibilities--profit maximization only versus stakeholders' view of social responsibility.
\end{abstract}

Keywords: experiential exercise on ethics, experiential exercise on social responsibility, teaching ethics and social responsibility, social responsibility debate in business courses

\section{Introduction}

There is no denying the fact that societies, across the globe, have seen frequent outbursts of major corporate scandals over the past several decades, well documented in the business literature and highly publicized in global media (Hunt \& Laverie, 2004; Low \& Ang, 2013). Moreover, international bribery has become so rampant that controlling bribery has become one of the top priorities of the governments worldwide (Gago-Rodríguez, Márquez-Illescas, \& Núñez-Nickel, 2018). Examples of companies involved in unethical leadership in recent times include Volkswagen (Kollewe, 2015; Parloff, 2018), Airbus, and FIFA (Orudzheva, Salimath, \& Pavur, 2018). It's not just the poor performing corporations who engage in unethical practices, high performers, such as HealthSouth corporation, were found to embroil themselves in unethical practices (e.g., cooking the books) to satisfy their investors' demands (Armstrong \& Balch, 2015). Quite frequently, unethical behaviors start on a small scale and grow steadily over time to become huge in nature; in other words, the ethical behavior of those involved erodes over time (Gino, Ordóñez, \& Welsh, 2014). For example, the former president of the board of directors for the NASDAQ stock exchange Bernard Madoff's scam started on a small scale, which eventually grew to an unbelievable amount of $\$ 65$ billion (Gino, et al., 2014).

Such behaviors often are deliberate and calculated, and are based on the assessment that perceived gain would outweigh the perceived cost of unethical behavior, with the chances of getting caught factored into the calculation (Klitgaard, 1988). While some companies survive the aftermath, many others disappear into oblivion, such as Enron, Arthur Andersen, WorldCom, Countrywide Financial Corporation, and Drexel Burnham Lambert. The spate of fraudulent and unethical behaviors naturally raised a serious concern about corporate social responsibility (Campbell, 2007), as such occurrences, in most part, are due to the leaders of these wrong doing corporations and their view of corporate social responsibility (Kothari, 2010; Low \& Ang, 2013).

These major incidents have consistently put business schools in the country under spotlight regarding the roles they play in developing corporate leaders, since many of these wrongdoers have a degree in business (Hunt \& Laverie, 2004). The onus is on business schools to produce graduates who will be ethical and weigh in social responsibility factor in their decision making. Researchers firmly believe that business schools can indeed be effective in instilling ethical behaviors and a sense of social responsibility among students (e.g., Hunt \& Laverie, 2004; Weber \& Glyptis, 2000 ) with the support of appropriately redesigned curriculums. Because of the significance, the Association to Advance Collegiate Schools of Business (AACSB International, 2015) has stepped in and revamped its accreditation 
standards to deal with such concern. The AACSB accreditation criteria now require business schools to integrate and promote ethical understanding and reasoning in program curriculums so that students are able to identify ethical issues and address the issues in a socially responsible manner.

The purpose of this paper is to present an experiential exercise, which can be incorporated in many business school courses to serve as a vehicle for students to critically examine the issues related to ethics and corporate social responsibility, and to enhance their insight and understanding of the issues. We begin with the existing dominant views of corporate social responsibility and provide rationale for using experiential approach to teach the concepts. Next, we discuss the learning goals, design, procedures as well as the debriefing issue related to the exercise, followed by our suggestions and conclusion.

\section{The Opposing Views of Corporate Social Responsibility}

Corporate social responsibility (CSR) is a highly debatable issue, and various groups in the society including the experts and corporate leaders define it differently and even take diametrically opposing positions at times. Since CSR involves questions regarding what is morally right or wrong, it is essentially an ethical issue (Dessler, 1998). The following are the two extreme views of CSR as reflected in the literature.

\subsection{Corporate Social Responsibility: The Profit Maximization View (PMV)}

Adam Smith, the father of the classical economic model, believed that the public interest was promoted by individuals pursuing their own economic self-interests (Samuelson, 1996). Basically, the classical view of social responsibility asserts that a corporation's primary goal is to maximize profits. In opposition to the widespread notion that corporations have social responsibility that goes beyond their stockholders or members, Milton Friedman (1962), the Nobel laureate economist, asserted:

There is one and only one social responsibility of business--to use its resources and engage in activities designed to increase its profits so long as it . . engages in open and free competition, without deception and fraud. . . . Few trends could so thoroughly undermine the very foundation of our free society as the acceptance by corporate officials of a social responsibility other than to make as much money for their stockholders as possible. (p. 133)

This view is still in force as manifested by the actual profit maximization behaviors of many corporations as well as opinions expressed by business leaders. For example, Robert J. Eaton, ex-chairman of Chrysler corporation ridiculed the idea of social responsibility and asserted that a corporation burdened with social responsibility will be at a tremendous disadvantage as far as its competition is concerned and will eventually lose out (Hammonds, 1996). This represents an extreme view of CSR in that corporations may pursue any actions, including those that could mean socially irresponsible behaviors if they can get away with it, in order to maximize profit and stockholders' value (Campbell, 2007).

\subsection{Corporate Social Responsibility: The Stakeholders' View (SHV)}

Campbell (2007), based on his literature review, concluded that it is difficult to pin down what exactly is a socially responsible corporate behavior, since it could mean different things in different contexts--place, time, and people. As Campbell (2007) stressed, the minimum standard for CSR require that corporations knowingly don't pursue any action which can harm their stakeholders (e.g., shareholders, employees, customers, communities, suppliers, government); in addition, corporations should rectify any harm caused to their stakeholders if and when discovered. However, Campbell (2007) noted, in contrast to his own position and supported by many other researchers, the conventional definition of CSR is more demanding, since it expects corporations to deliberately make decisions and take actions in order to enhance the social (stakeholders') welfare, which go well beyond the economic and legal interests of corporations. For example, the stakeholder theory presented by Beauchamp and Bowe (1993) emphasized that the decisions and actions of the corporation should be designed to ensure the rights and benefit of its stakeholders, e.g., its customers, suppliers, shareholders, employees, and local communities. Moreover, these stakeholders should be allowed to participate in corporate decisions which affect them significantly. Starbucks CEO Howard Schultz, in his recent statement below (Faroohar, 2015), echoed the conventional or stakeholder's view of CSR:

The private sector simply has to take a larger role than they have in the past. Our responsibility goes beyond the P (profit) \& L (loss) and our stock price. We have to take care of people in the communities that we serve. If half . . . or . . a third of the country doesn't have the same opportunities as the rest going forward, then the country won't survive." (p. 21) 
Based on the preceding discussions on the PMV and SHV, it is obvious that CSR is a highly debatable issue and is relative to different groups in the society. Therefore, an experiential exercise involving CSR should provide a tremendous learning opportunity for students, since they can critically examine this contentious and evolving issue in an interactive classroom setting.

\section{Rationale for Using Experiential Exercise}

Over and above the chronic and persistent problem of student motivation in classrooms (Hancock, 2002; Pintrich, 1994), the advent of various internet-based smart tools (e.g., cell phone, tablet, laptop) in classrooms now stand as an invincible wall between the college professors and the student learning. Given that motivation in classrooms has become a hard-to-achieve and moving target, educators are increasingly questioning the effectiveness of the traditional lecture-based teaching and asserting that the knowledge transfer system has to be modified in order to ensure that students acquire essential skills, such as communication, critical thinking, and problem-solving (Zapatero, Maheswari, \& Chen, 2012). In order to enhance student engagement in classrooms, educators are increasingly complementing the lecture-based approach with experiential learning in classrooms (Kolb \& Kolb, 2006). Experiential exercises can also promote human or soft skills required to work with and through other people, communicate, and lead (Debnath, Tandon, \& Pointer, 2007).

Research findings (e.g., Baker \& Comer, 2012; Hu, Kuh, \& Li, 2008; Zapatero et al. 2012) indicate that student engagement and learning are enhanced with the incorporation of experiential exercises in business school courses, among others. Researchers were successful in enhancing student motivation using experiential exercises in areas such as value chain analysis (Sheehan \& Gamble, 2010), financial analysis using trading room (Stewart, Houghton, \& Rogers, 2012), and ethics in business (Baker \& Comer, 2012). Therefore, an experiential exercise on ethics and social responsibility would complement the traditional teaching approaches and enhance student engagement and learning in classrooms.

Specifically, this experiential exercise can be utilized by students to critically examine two diametrically opposing views of corporate social responsibilities--profit maximization only (PMV) versus stakeholders' view (SHV) of social responsibility.

\section{Learning Goals for the Experiential Exercise}

Many business courses in areas such as management, marketing, accounting, and finance deal with ethics and CSR issues. This experiential exercise can be easily integrated into any of these courses. The purpose of this exercise is to help students critically examine, in a highly involved setting, whether (1) profit maximization should be the only CSR of a corporation, (2) corporations have responsibilities to various stakeholders or the society, and (3) being ethical is important. It also provides a mechanism for examining and applying various theories and research findings related to CSR, as a basis for supporting and communicating their own position or point of view. Finally, students are likely to experience the dynamics of intergroup competition and will be challenged to 'think on their feet' as they will be required to defend their own positions on-the-spot during counter arguments.

\section{Pre-debate Setup and Preparation}

\subsection{Advance Preparation}

It is important that students are primed with currently available theories and concepts relevant to ethics and social responsibilities prior to the exercise, so that they can participate in the debate as knowledgeable business students and guide their thoughts and formulations in the light of these theoretical developments. Some suggested topics may include the following: Carroll's (1979) four responsibilities of business, Kohlberg's (1976) levels of moral development, and Cavanagh's (1990) basic approaches to ethical behavior.

\subsection{Group Formation and Role Assignment}

The students should be assigned, as appropriate, either to play individual or group roles as follows:

a) The PMV group: The primary group to support the profit maximization view

b) The SHV group: The primary group to support the stakeholders' view

c) Eight stakeholders' groups: Stockholders, customers, suppliers, employees, managers, community, government, and special interest groups. The stakeholders' groups are free to support either position (PMV or SHV); the use of the term 'stakeholder' for these groups does not necessarily imply that they are there to support one group only and oppose the other group. While PMV or SHV groups try to assert themselves, their positions are subject to scrutiny, attack, or may receive support from any of the stakeholder(s). 
d) Judges, a moderator, and a recorder.

Table 1 exhibits various roles and the suggested sizes for each role. The total number of participants can be reduced (if the class size is small) by having fewer stakeholder groups or assigning fewer students in each group; the number of participants can be increased by just doing the opposite. Students without any role assignment may perform the role of observers.

During the pre-debate meeting, the instructor should distribute both the PMV and SHV statements, described in the next section, to all students. Each student should be assigned to play a specific role (e.g., the PMV, the SHV, or a stakeholder) and instructed to prepare arguments to support their own assigned positions and develop counter-arguments for the other applicable roles. The judges should prepare the criteria based on which they would evaluate the two opposing groups and decide on a winner. The instructor, if necessary, may provide some directions to help the judges in formulating the criteria. Each of the two competing groups (the PMV and the SHV) should designate a spokesperson who will make the presentation on its behalf. Moreover, the students should be given an idea of the physical setting or how the groups or individuals will be positioned during the debate. Figure 1 provides a tentative idea about the placement of various groups or role-players.

Table 1. Various roles and suggested number of participants in each role

\begin{tabular}{ll}
\hline Groups/Individual roles & Suggested number of participants \\
\hline PMV \& SHV Groups & 2 groups x 4 members per group, Total 8 \\
Eight Stakeholders' Groups & 8 groups x 2 members per group, Total 16 \\
Judges & 3 members \\
Debate Moderator & 1 member \\
Recorder & 1 member \\
Total & 29 participants \\
\hline
\end{tabular}

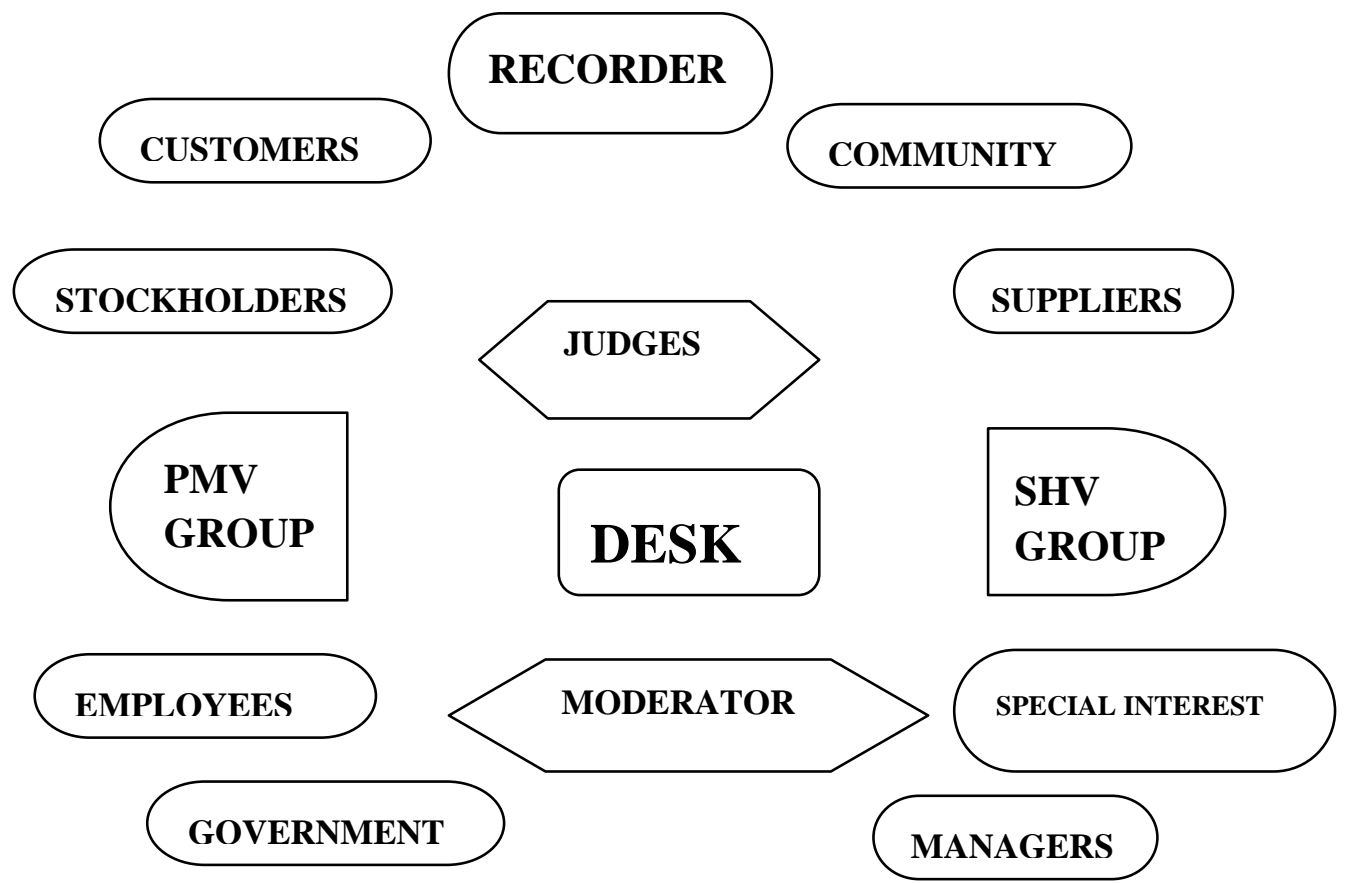

Figure 1. The suggested positions of the role players in the PMV versus SHV debate 


\subsection{Position Statements for the PMV and the SHV}

The PMV group attempts to provide arguments to support that profit maximization should be the only social responsibility for the businesses, and present counter-arguments for the SHV position. The following statement was developed based on the discussions presented earlier.

The PMV position statement: The only social responsibility of corporations is to maximize profits and shareholders' value. Social responsibility in any form other than to make as much money as possible for a corporation and its shareholders would be burdensome and undermine the spirit of free economy.

The SHV group should assert that corporations have responsibilities to the society or stakeholders, which go well beyond profit maximization only. The following statement for this group was developed based on the available literature.

The SHV position statement: The social responsibility of corporations has to extend well beyond the self-serving interest of maximizing profit. Corporations must ensure the welfare, rights, and benefits of its stakeholders as well as allow them to be a part of the decision-making process on issues that may affect them significantly.

\subsection{Additional Information Related to the Exercise}

a) Time required: Approximately 80 minutes.

b) Special materials: None.

c) Special physical requirement: The classroom should have movable tables and chairs so that they can be arranged to position different groups appropriately.

\section{On the Day of the Exercise: The Debate Process}

On the scheduled day of the debate, students should sharply be on time in the class, as every minute counts. The instructor should ensure that the arrangement is done promptly to get the debate started without any hitch or delay. The tentative time allocation and the essential steps are described as follows.

Step 1: 10 Minutes. The classroom furniture is reorganized and the role-players are positioned similar to Figure 1 or as appropriate to facilitate the debate. At the start of the session, all groups are given about 10 minutes to finalize their preparation. The groups should be seated apart and scattered throughout the classroom. The two competing groups should be so positioned that they are not able to eavesdrop on the opposing group's conversation.

Step 2: 25 minutes. a) The moderator initiates the debate by giving each of the PMV and the SHV groups one minute to make its position statement, preferably starting with the PMV group. From this point, groups are alternated for providing their responses. b) Next, each group is allowed five minutes to make its presentation and arguments to establish its position. c) The recorder posts the points (and counterpoints subsequently) made by each group on the board in "shorthand" style. d) Once both groups complete their presentations, a short pause is taken (about five minutes) to allow both groups to prepare their rebuttal. e) Each group is then given two minutes to present their rebuttal. f) To exhaust any additional arguments between the two groups and to accommodate a free-flowing exchange, each group is allowed two one-minute opportunities for arguments and rebuttal. g) At this point, the moderator announces the end of the exchange between the PMV and the SHV groups.

Step 3: Up to 24 minutes. The moderator then invites each stakeholder group and allows one minute to either make a presentation or ask a maximum of two questions which can be directed to either or both of the PMV and the SHV groups. The issues could be related to the arguments made by the two primary groups or reflect the stakeholder group's own concern. For each stakeholder's questions or comments, the moderator limits the response time to two minutes from either the PMV, the SHV, or both groups, as appropriate.

Step 4: 8 minutes. Next. The judges take about five minutes to finalize their decision. They then take about three minutes to announce the winner to the class and present the basis of their decision.

Step 5: 10 minutes. The instructor may initiate a brief discussion involving the debate and the issues noted on the board, sum up the major learning points, and conclude the session.

\section{Debriefing the Exercise}

The role-playing exercise usually leads to highly charged exchanges with serious student involvement. Students come to grips with the complex nature of the corporate social responsibility and the reality of hard-to-achieve balancing act across the stakeholders' demands or between corporate and stakeholders' interests. During the next 
meeting, the instructor should facilitate an open and free flowing discussion from the students, who are likely to be more level-headed after the post-debate cooling period. Students should be encouraged to reflect on their experiences from the exercise, which should be the most valuable part of their learning. A follow up discussion based on some major unethical incidents, such as Dow Corning's breast implant business (Byrne, 1995), Volkswagen automobile emissions scandal (Kollewe, 2015), or Bausch and Lomb's profit maximization venture (Barnathan, 1995), should provide the class further ground to examine the PMV and the SHV positions. These corporate wrongdoings may also be examined in terms of the theoretical frameworks offered by various researchers, such as Carroll (1979), Kohlberg (1976), and Cavanagh (1990). It may be useful to emphasize to students that the legal, ethical, and even the discretionary responsibilities have moving standards, which call for a more careful managerial decision making.

Students should also be reminded that both views of the CSR-the PMV and the SHV--have their own share of criticisms. As discussed earlier, with the PMV, a corporation could be prone to pursuing any action including socially irresponsible behaviors if it helps to maximize profit and stockholders' value (Campbell, 2007). Similarly, with the SHV, the stakeholders may perceive that they have the right to free lunch without any concomitant obligation or responsibility (Phillips, Freeman, \& Wicks, 2003; Sternberg, 1997). The debate frequently unfolds arguments along these lines from the PMV, the SHV, or individual stakeholder groups.

\section{Additional Thoughts and Conclusion}

As our experience indicates, this exercise would be more effective if students prepare their roles prior to the exercise. Also, it is important to select (1) students for the PMV and the SHV groups who are able to articulate their views and (2) the judges who have good analytical and decision-making skills. The moderator must enforce the time limit, since there is a tendency for the role players to exceed the allocated time. The moderator should also ensure that no more than one group speaks at any one point in time because, at times, excitement causes several groups to exchange arguments. The exercise may be modified and adapted to a certain extent at the discretion of the instructor as long as it serves the purpose. Also, if needed, the instructor may assume the role of the moderator, and graduate assistants--who are likely to be more competent--may fill in the role of the judges.

In conclusion, with the frequent eruption of unethical and large-scale irresponsible behaviors from corporations on a global scale, business schools across the country are under increasing pressure from the society in general and AACSB, in particular, to inculcate in their graduates a sense of ethics and social responsibility. While teaching CSR in classrooms can be a daunting task and the theoretical lecture-based explanations may fall short of the learning goal, this experiential exercise provides an interactive and highly involving mechanism for helping students gain insights on the complexity and conflicting nature of CSR. The exercise also facilitates an application of the available theoretical frameworks and provides a mechanism for examining unethical corporate incidents during the debriefing stage to enhance students' learning.

\section{References}

Armstrong, R., \& Balch, D. (2015). The tale of two CFOs: The banality of wrongdoing at HealthSouth Corporation. Journal of Legal, Ethical, and Regulatory Issues, 18(2), 71-85.

Association to Advance Collegiate Schools of Business (AACSB International). (2013). Eligibility Procedures and Accreditation Standards for Business Accreditation. Retrieved January 31, 2015, from http://www.aacsb.edu/ /media/AACSB/Docs/Accreditation/Standards/BusinessStds_2013_Update-Jan2015_Fi nal.ashx

Baker, S.D., \& Comer, D.R. (2012). Business Ethics Everywhere: An Experiential Exercise to Develop Students' Ability to Identify and Respond to Ethical Issues in Business. Journal of Management Education, 36(1), 95-125. https://doi.org/10.1177/1052562911408071

Barnathan, J. (1995, October). Blind ambition. Business Week, 78-92.

Beauchamp, T., \& Bowe, N. (1993). Ethical Theory and Business. Englewood Cliffs, NJ: Prentice Hall.

Byrne, J.A. (1995, October). Informed consent. Business Week, 104-116.

Campbell, J. (2007). Why would corporations behave in socially responsible ways? An institutional theory of corporate social responsibility. Academy of Management Review, 32(3), 946-967. https://doi.org/10.5465/amr.2007.25275684

Carroll, A.B. (1979). A three-dimensional conceptual model of corporate performance. Academy of Management Review, 4, 497-505. https://doi.org/10.5465/amr.1979.4498296

Cavanagh, G.F. (1990). American Business Values (3rd ed.). Englewood Cliffs, NJ: Prentice Hall. 
Debnath, S., Tandon, S., \& Pointer, L. (2007). Designing business school courses to promote student motivation: An application of the job characteristics model. Journal of Management Education, 31(6), 812-831. https://doi.org/10.1177/1052562906290914

Dessler, G. (1998). Management. Upper Saddle River, N. J.: Prentice Hall.

Foroohar, R. (2015, February). Starbucks for America. Time, 18-23.

Friedman, M. (1962). Capitalism and Freedom. Chicago: University of Chicago Press.

Gago Rodríguez, S., Márquez Illescas, G., \& Núñez Nickel, M. (2018). Denial of corruption: voluntary disclosure of bribery information. Journal of Business Ethics. https://doi.org/10.1007/s10551-018-3989-9

Gino, F., Ordóñez, L., \& Welsh, D. (2014). How unethical behavior becomes habit. Harvard Business Review Blog. Retrieved from https://hbr.org/2014/09/how-unethical-behavior-becomes-habit/

Hammonds, K.H. (1996, March). Writing a new social contract. Business Week, 60.

Hancock, D.R. (2002). Influencing postsecondary students' motivation to learn in the classroom. College Teaching, 50(2), 63-68. https://doi.org/10.1080/87567550209595877

Hu, S., Kuh, G.D., \& Li, S. (2008). The effects of engagement in inquiry-oriented activities on student learning and personal development. Innovative Higher Education, 33(2), 71-81. https://doi.org/10.1007/s10755-008-9066-z

Hunt, S. \& Laverie, D. (2004). Experiential learning and the Hunt-Vitell theory of ethics: Teaching marketing ethics by integrating theory and practice. Marketing Education Review, 14(3), 1-14. https://doi.org/10.1080/10528008.2004.11488874

Klitgaard, R. (1988). Controlling corruption. Berkeley: Univ of California Press.

Kohlberg, L. (1976). Moral stages and moralization: The cognitive-development approach. In T. Lickona (Ed.), Moral Development and Behavior. New York: Holt, Rinehart \& Winston.

Kolb, A.Y., \& Kolb, D.A. (2006). Learning styles and learning spaces: A review of interdisciplinary application of experiential learning in higher education. In Sims, R. \& Sims, S. (Eds.), Learning styles and learning: A key to meeting the accountability demands in education. Hauppauge, NY: Nova.

Kollewe, J. (2015, December). Volkswagen emissions scandal-timeline. The Guardian. Retrieved from https://www.theguardian.com/business/2015/dec/10/volkswagen-emissions-scandal-timeline-events

Kothari, V. (2010). Executive Greed. New York: Palgrave McMillan. https://doi.org/10.1057/9780230109650

Low, P., \& Ang, S. (2013). Confucian ethics, governance and corporate social responsibility. International Journal of Business and Management, 8(4), 30-43.

Orudzheva, L., Salimath, M., \& Pavur, R. (2018). Vortex of corruption: Longitudinal Analysis of Normative Pressures in Top Global Companies. Journal of Business Ethics. https://doi.org/10.1007/s10551-018-4022-z

Parloff, R. (2018, February). How VW Paid \$25 Billion for 'Dieselgate'-and Got Off Easy. Fortune. Retrieved from http://fortune.com/2018/02/06/volkswagen-vw-emissions-scandal-penalties/

Phillips, R., Freeman, R., \& Wicks, A. (2003). What stakeholder theory is not. Business Ethics Quarterly, 13(4), 479-502. https://doi.org/10.5840/beq200313434

Pintrich, P.R. (1994). Student motivation in the college classrooms. In K. W. Prichard \& R. M. Sawyer (Eds.), The handbook of college teaching: Theory and applications. CT: Greenwood Press.

Samuelson, R.J. (1996, December). The spirit of Adam Smith. Newsweek, 63.

Sheehan, N.T., \& Gamble, E.N. (2010). JetFighter: An experiential value chain exercise. Journal of Management Education, 34(2), 224-248. https://doi.org/10.1177/1052562909358554

Sternberg, E. (1997). The defects of stakeholder theory. Corporate Governance: An International Review, 5(1), 3-11. https://doi.org/10.1111/1467-8683.00034

Stewart, A.C., Houghton, S.M., \& Rogers, P.R. (2012). Instructional Design, Active Learning, and Student Performance Using a Trading Room to Teach Strategy. Journal of Management Education, 36(6), 753-776. https://doi.org/10.1177/1052562912456295

Weber, J., \& Glyptis, S. (2000). Measuring the impact of business ethics course and community service experience on students' values and opinions. Teaching Business Ethics, 4, 341-358. https://doi.org/10.1023/A:1009862806641

Zapatero, E., Maheshwari, S., \& Chen, J. (2012). Effectiveness of active learning environment: Should testing methods be modified. Academy of Educational Leadership Journal, 16(4), 101-114. 